\title{
Environmental investigation on recycling the treated sewage to feed the groundwater, Iran
}

\begin{abstract}
Domestic, industrial and agricultural sewage contaminates the limited groundwater reservoirs, and makes water extraction more cumbersome in numerous parts of Iran. Impurity was affected by effluent depletion wealthy in ammonia. The alteration in ammonia condensation was mostly governed by the immigration of the contamination plume under nitrification in groundwater. The nitrification level was presumably traced by alters in dissolved oxygen and potentially manganese. Nitrogen pollution of natural water is a typical obstacle for diverse lands throughout the universe. Computer simulation and ground perceptions demonstrate the detracting situations organized under joint effects of anthropogenic items and suitable natural conditions, such as the low-level topography in which reduced water exchange rate can happen. In European Union countries, exposure sewage mud on agricultural terrains is surrounded by guidance. It was established that solitary usage of waste-water mud was useful for extension of herbage cover. Waste-water mud from food industry prepared herbage nutrients effectively used by the herbs. Therefore, the consequences of the experiences displayed that the imperceptible extrication of macronutrients from waste water mud was fully applied by herbages to stimulate their formation and extension. The rapid growth of proactive industries in this country, which is by and large due to ignorance towards the adequate water sources, has augmented the complications and has overshadowed the underground water in plains.
\end{abstract}

Refined water (treated wastewater) can possibly help preserve the subterranean water since overtreatment ensures decent sewage management. Natural filtration under the ground eliminates the need for costly advanced treating procedures. Furthermore, aquifers provide a natural mechanism to transport the treated subterranean water and eliminate the surface storage and its problems, such as evaporation and algal growth. Supplementing water into a geological formation through various methods and equipment is called "Artificial Feeding". This study deals with the strategies, challenges, and the mechanisms to remove the soil pollutants.

Keywords: reuse water, wastewater, artificial feeding, removal mechanism
Volume I Issue 3 - 2018

\author{
Saeid Eslamian,' Khadijeh Pasar, ${ }^{2}$ Zahra \\ Majidifar, ${ }^{3}$ Kaveh Ostad Ali Askari, ${ }^{4}$ Vijay P \\ Singh, ${ }^{5}$ Nicolas R Dalezios ${ }^{6}$ \\ 'Department of Water Engineering, Isfahan University of \\ Technology, Iran \\ ${ }^{2}$ Environmental Science Department, Islamic Azad University, \\ Iran \\ ${ }^{3}$ Department of Agronomy and Plant Breeding, Lorestan \\ University, Iran \\ ${ }^{4}$ Department of Civil Engineering, Islamic Azad University, Iran \\ ${ }^{5}$ Department of Biological and Agricultural Engineering, Texas A \\ and M University, USA \\ 'Laboratory of Hydrology, Agricultural University of Athens, \\ Greece
}

Correspondence: Kaveh Ostad Ali Askari, Department of Civil Engineering, Isfahan (Khorasgan) Branch, Islamic Azad University, Isfahan, Iran, Tel +983I 3535400 I 9, Email Koa.askari@khuisf.ac.ir

Received: May 09, 2018 | Published: June 1I, 2018

\section{Introduction}

Different methods of treatment in which physical forces are significant are known as "Treatment Unit Operations". And, the approaches in which chemical reactions and primary biology eliminate the pollutants are called "Treatment Procedures". Nowadays, these operations and procedures are associated, which is recognized as initial and final phases of treatment. ${ }^{1}$ The initial treatment includes physical treatment operations, such as filtering the litter and the sediment in order to separate the floating and the settled material in the wastewater. ${ }^{2}$ However, in the second phase, chemical and biological procedures remove most of the minerals. During the final phase, extra operations and treatments take out the other pollutants like nitrogen and phosphor, which are not greatly removed in the second phase. ${ }^{3}$ Ground treatment methods, currently known as natural systems, utilize a combination of physical, chemical and biological techniques to filter the water properly. ${ }^{4}$

Nitrite and Nitrate are among the pollutants which have increased due to the overpopulation. ${ }^{5}$ It should be taken into account in treatment. Nitrate, which is the final stage of nitrogen oxidation, can cause Globinma in infants. ${ }^{6}$ It can also cause the formation of Nitrosamine in sewage water. ${ }^{7}$ Furthermore, heavy metals are among the main pollutants with ion exchange power. ${ }^{8}$ They are present in both underground water and sewage water. ${ }^{9}$ These pollutants are frequently absorbed by clay minerals, such as chlorite and the present minerals before entering the underground water. ${ }^{10}$

\section{The aims of artificial feeding}

Among the aims of artificial feeding, improving the quality of water (by monitoring the temperature and refining the bacteria), increasing the underground water, balancing the surface water, preventing the entrance of salty water into fresh water aquifers, avoiding the depression of the ground, storing water for future use, gaining energy from the warm water, and distributing underground water for wells are to cite. ${ }^{11}$ Water pollution happens mostly due to inorganic and organic contaminants, such as nutrients, heavy metals and insistent organic contaminants. ${ }^{12}$ For the modelling and optimization of contaminants elimination, artificial intelligence has been applied as a major tool in the empirical plan that can produce the optimal useful inconstant, since artificial intelligence has lately obtained a enormous progress. ${ }^{13}$

\section{Artificial feeding methods}

The most frequent methods for artificial feeding are: 


\section{Pond method}

In this method, water is treated by either raising the boundary soil of the pond or excavating the depth of the pond. It should be noted that water should not contain any particles as large as the silt because they can clog the empty spaces. The computer simulation of hydrodynamics water modality in ponds is an extending tool that valuable learning until realizing their interior procedures and interplays. Pond plan includes various physical, hydrological, geometrical, biological and dynamic uncertain to prepate high hydrodynamic knowledge and maximum layer usage levels. ${ }^{14}$

\section{Flood method}

Flood method consists of a variety of techniques, such as flooding the surface, using flooding systems, improving the canals, hill filtration, and pond filtration. All of the mentioned techniques depend largely on the type of soil, porosity, the depth of the underground water, district topography, the quantity and the quality of the treated water. ${ }^{15}$ This method is divided into two ways: direct injection and the injection in shallow and unenriched zones. Direct injection pumps water into the underground water zone. ${ }^{11}$ It is used in areas where the underground water is deep and/or hydrology is not optimal for flood distribution. The advantage of injection in unenriched areas is the low costs. On the contrary, one disadvantage is that it does not ensure reverse washing and a good clogging can collapse it entirely. ${ }^{16}$

\section{Materials and methods}

\section{Natural removal procedures}

The materials which are bigger than the soil particles such as some bacteria can separate water from the soil, and are removed by filtration and sediment. Viruses, however, are eliminated by surface attraction and reaction to the aerobic bacteria. ${ }^{13}$ The gradual accumulation of the particles in one layer lowers the efficiency of the filtration. Constructed wetlands have been applied as a green technology to treat several sewages for many decades. ${ }^{17}$ Constructed wetlands propose a land-intensive, low-energy, and less-operational-needs intermittent to standard treatment systems, mainly for small societies and distant places. However, the supportable action and prosperous usage of these systems stay a compete. The plan parameters and usable situations of Constructed wetlands containing plant species, layer types, water depth, hydraulic load, hydraulic retention time and feeding mode depended to the supportable function for sewage conducts were then considered. finally, amending the consistency and sustainability of Constructed wetlands were underlined. ${ }^{18,19}$ However commercially existent biosurfactants are environmentally sociable and effectively delete heavy metals from soil, they are overpriced. ${ }^{20}$ Economical humic substances from wastewater mud mixture could effectively delete copper and cadmium from extremely polluted sandy clay loam and clay. ${ }^{21}$ Humic substances display potential for using soils extremely imbued with heavy metals, and Humic substances from other principles should be experienced with these and other pollutants. ${ }^{22}$ In the constructed wetlands, biodegradation, substrate adsorption and plant uptake all acted determined parts in decreasing the burdens of nutrients, antibiotics and antibiotics and antibiotic persistence genes, but biodegradation was the most significant process in the elimination of these contaminants. ${ }^{23}$ Biological phosphorus elimination has been illustrated to be successfully attained in the aerobic/extended-idle sewage treatment regime in prior bench-scale studies. To time, anyway, its possibility has never been appraised by any full-scale research. It proposes an absorbent choice for Biological phosphorus elimination from carbohydrate-rich sewages and also prepares an archetype for sewage treatment in distant zones. The floating solids that are not held by soil will be eliminated by filtration and surface attraction in a soil profile. As an example, soil particles and floating solids are, by far, smaller than what is held by soil through direct flow, hydrodynamic movement, distribution and sediments. Thus, these particles are attracted by the static soil network..$^{24}$ In order to rectify and preserve the non-minerals in the soil, chemical, physical, and microbiological reactions, such as ionic exchange, sediment, surface attraction, chelation, complication, and mineral oxidation are required. ${ }^{5}$ The majority of the minerals can be rectified. In contrast, non-minerals such as chlorine, sodium and sulfate are not affected by the land pores. For example, iron and phosphor can be rectified up to 90 percent, which is done by sediment and surface attraction. However, the potential of the soil to remove them diminishes through time.

The minerals which are soluble during the feeding phase are prone to be attracted by the surface and decompose biologically. Decomposition is basically done by sticky microorganisms. And depends largely on the minerals and electron attractors such as solved oxygen and nitrates. ${ }^{25}$ Large particles in water aquifers like sand can clog the pores. Decomposable compounds may not survive in aerobic and non-aerobic underground water. Nevertheless, the chemical compounds with the high potential to dissolve are worrisome. Moreover, some groups of compounds have complicated biological decomposition and require a long time. ${ }^{14}$ The final products of the decomposition under non-aerobic conditions include carbon dioxide, nitrogen, sulfate and methane. In case of aerobic conditions, carbon dioxide, sulfate, nitrate, phosphate and water will be produced. ${ }^{26}$ Nitrate and ammoniac are two forms of refined water. The secondary fluid including nitrogen ammoniac has the density of higher than $20 \mathrm{mg} \mathrm{N} / \mathrm{L}$. It should be noted, however, that the fluid after nitrogen rectification contains nitrogen nitrate with the density of lower than $10 \mathrm{mg} \mathrm{N} / \mathrm{L} .{ }^{6}$ Nitrogen ammoniac requires the most oxygen in the secondary fluid. Nitrogen can be efficiently rectified during the treatment even though the underground water-aquifer filtering system can adequately reduce the density of the nitrogen..$^{18}$ Whenever ammoniac exists in refined water, it should be rectified by surface attraction in damp conditions.

Damp conditions means there is not enough oxygen to support nitrification. Indeed, nitrification of the ammoniac on the surface takes place during the dry period when there is fresh air in the unenriched soil. Nitrate is partially absorbed, and the water flows through the soil-aquifer under the ground..$^{27}$ Damp and dry periods are required for nitrification above the unenriched soil. As a matter of fact, most of the ignored mobile nitrate in soil exists in the deep non-aerobic areas of land where ammoniac is also present. ${ }^{25}$ The prolonged dry period causes the more aeration in the depth of soil, which absorbs more ammoniac. The prolonged damp period, nonetheless, increases the absorption of ammoniac along with its dwindling. Preserving the microorganisms under soil which cause illness hinge upon some factors, such as climate, soil compound, microflora of the soil, the amount and type of the microorganism. In a temperature lower than $4^{\circ} \mathrm{C}$, some microorganisms can survive for months and years. Gradual death doubles every $10^{\circ} \mathrm{C}$ between 5 to $30^{\circ} \mathrm{C} .^{27}$ Rain is a factor to move the bacteria in alkali soil or the soil with plenty of minerals. Wherever the low $\mathrm{pH}$ results in the absorbance of more viruses, the bacteria and bigger organisms are rectified after a short distance. ${ }^{13}$ 
Factors that influence the movement of the viruses in underground water are displayed in Table $1 .{ }^{28}$ Improving the treatment can minimize the number of the microorganisms in underground water more than what the place and the feeding system management can do. ${ }^{27}$ In case the microorganisms grow in underground water, oxidations rises and affects the rectification. ${ }^{29}$

Table I Factors affecting the movement of viruses in groundwater

\begin{tabular}{ll}
\hline Factor & Details \\
\hline Soil type & $\begin{array}{l}\text { The soil with micro-tissue is much better than the light soil. } \\
\text { Iron oxide raises the surface absorbance. Algal soil is not } \\
\text { optimal for surface attraction. }\end{array}$ \\
& $\begin{array}{l}\mathrm{pH} \text { can increase the surface attraction. Though this is not } \\
\text { certain. }\end{array}$ \\
pH & $\begin{array}{l}\text { Cations raise the surface absorbance, and decrease the } \\
\text { repellant factors of the viruses. Rain can dissect the viruses } \\
\text { from the soil. }\end{array}$ \\
Cation & $\begin{array}{l}\text { They compete with the viruses on the place of the } \\
\text { absorbance. No competition exists in ordinary fluids in } \\
\text { the sewage. Humus and Folic acid } 2 \text { decrease the surface } \\
\text { absorbance. }\end{array}$ \\
$\begin{array}{l}\text { Dissolved } \\
\text { minerals }\end{array}$ & $\begin{array}{l}\text { The absorbance of the virus depends on the type of the } \\
\text { virus. }\end{array}$ \\
Virus type & $\begin{array}{l}\text { Faster flow leads to lower surface absorbance of the virus. } \\
\text { Fluid pace }\end{array}$ \\
$\begin{array}{l}\text { Enriched } \\
\text { and } \\
\text { unenriched } \\
\text { fluid }\end{array}$ & \begin{tabular}{l} 
Viruses move the least under unenriched conditions. \\
\hline
\end{tabular}
\end{tabular}

\section{Conclusion}

With regards to the water resources in Iran and the sewage pollution, utilizing the treated wastewater in order to feed the underground water could be truly prudent. In this respect, although soil can act as a refiner, the necessity of treatment based on standards should not be taken for granted. The restrictions to feed the underground water relates the health concerns, economic justification, physical limits, law restrictions, qualitative bounds, and the availability. Among these issues, health matters the most, though; which must be monitored in all projects. In the aridity tension condition, one of the implant and trustworthy originals for adjusting the water schedules is the water taken from runoff of the waste-water refinery. To be sure, improvement and optimal benefit of runoff from the waste water refinery is feasible prepared that together needed criterions and modality reins for both runoff and the groundwater are apperceived. ${ }^{30}$ The liberation of issuant from sewage remedy herbages can affect receiving water bodies by changing water temperatures. A major sewage treatment herbage could not match the new request of civic surroundings. ${ }^{31}$

\section{Acknowledgements}

None.

\section{Conflict of interest}

The authors declare that there is no conflict of interest.

\section{References}

1. Bazza M. Experience of F.A.O on wastewater Reuse in the Near East
Region, Regional Workshop on Water Reuse in the Middle East and North Africa, Cairo, Egypt. 2001.

2. Ravindra KD, Jorge de B, Raman M, et al. Environmental Impact, Case Studies and Standards and Specifications. Sustainable Construction Materials opper Slag. 2017. p. 279-308.

3. Jonas L, Harald G, Scott McDonald. When water saving limits recycling: Modelling economy-wide linkages of wastewater use. Water Res. 2016;88:972-980.

4. Saabet R Alieh, Shanesaz M Javad, Hosseinifar A. Reusing water in Iran, The local workshop on the reutilizing water in the Middle East and North Africa, Egypt. 2001.

5. Abdul Raheem, Vineet SS, Jun He, et al. Opportunities and challenges in sustainable treatment and resource reuse of sewage sludge: A review. Chemical Engineering Journal. 2018;337:616-641.

6. Rajasulochana P, Preethy V. Comparison on efficiency of various techniques in treatment of waste and sewage water - A comprehensive review. Resource-Efficient Technologies. 2016;2(4):175-184.

7. Sewage Engineering, Metkaf Vadi Engineering Co. Revised by George Chupano Glose, Franklyne Al, Bourten, Translated by Abrishamchi, Abbas A, Behshid J, 1997.

8. Zhuo C, Huu H, Wenshan G, et al. A comprehensive framework for the assessment of new end uses in recycled water schemes. Sci Total Environ. 2014;470-471:44-52.

9. Scott VJ, Bruk B, Thomas AD, et al. Optimal sizing and dispatch for a community-scale potable water recycling facility. Sustainable Cities and Society. 2018;39:225-240.

10. Eslamian Seyed S, Tarkash E Saleh, Hedayat E. Reusing the treated sewage by feeding the underground water in order to increase the sustainable water resources, The first international conference on water resources. Shahroud. 2009.

11. Van der Bruggen B. The Global Water Recycling Situation. Sustainability Science and Engineering. 2010;2:41-62.

12. Khan MN, Mobin M, Abbas ZK, et al. Fertilizers and Their Contaminants in Soils, Surface and Groundwater. Encyclopedia of the Anthropocene. 2018;5:225-240.

13. Torquato LD, Pachiega R, Crespi MS, et al. Potential of biohydrogen production from effluents of citrus processing industry using anaerobic bacteria from sewage sludge. Waste Management. 2017;59:181-193.

14. de Jong J, Akselsson C, Egnell G, et al. Realizing the energy potential of forest biomass in Sweden - How much is environmentally sustainable? Forest Ecology and Management. 2017;383:3-16.

15. Khrraz ,Munther. Use of Treated for Irrigation in Madaba. Egypt. 2001.

16. Peng YANG, Yan-zhi GUO, Ling QIU. Effects of ozone-treated domestic sludge on hydroponic lettuce growth and nutrition. Journal of Integrative Agriculture. 2018;17(3):593-602.

17. Priyanka Jamwal, Atul K Mittal. Reuse of treated sewage in Delhi city: Microbial evaluation of STPs and reuse options. Resources, Conservation and Recycling. 2010;54(4):211-221.

18. Chen M, Sun F, Shindo J. China's agricultural nitrogen flows in 2011: Environmental assessment and management scenarios. Resources, Conservation and Recycling. 2016;111:10-27.

19. Chen Z, Ngo HH, Guo W. A critical review on sustainability assessment of recycled water schemes. Sci Total Environ. 2012;426:13-31.

20. Susmita DS, Meenakshi G, Amit Kumar. 4-Major environmental issues and new materials. New Polymer Nanocomposites for Environmental Remediation. 2018;77-97. 
21. Bouwer H. Role of Groundwater Recharge in Treatment and Storage of Wastewater for Reuse. Water Science Technology. 1991;24(9):295-302.

22. Chai HK, Abdul WM, Fatihah S. Recycling of oleochemical wastewater for boiler feed water using reverse osmosis membranes - A case study. Desalination. 2011;271(1-3):178-186.

23. Izabella de AB, Ellie AL, Sabrina BL, et al. Modeling the exposure risk of the silver catfish Rhamdia quelen (Teleostei, Heptapteridae) to wastewater. Ecological Modelling. 2017;347:40-49.

24. James G Speight. Chapter Eight: Environmental Regulations. Environmental Inorganic Chemistry for Engineers. 2017;383-426.

25. Sacchi E, Acutis M, Bartoli M, et al. Origin and fate of nitrates in groundwater from the central Po plain: Insights from isotopic investigations. Applied Geochemistry. 2013;34:164-180.

26. Zhaoyang Z, Aicheng C. Simultaneous removal of nitrate and hardness ions from groundwater using electrodeionization. Separation and Purification Technology. 2016;164:107-113.
27. Cristina P, Damià B. Synthetic organic compounds and their transformation products in groundwater: Occurrence, fate and mitigation. Sci Total Environ. 2015;503-504:32-47.

28. Luciane B, Valdemar S, Renato CS, et al. Gaseous emissions from sewage sludge combustion in a moving bed combustor. Waste Manag. 2015;46:430-439.

29. Sivan K, Michael B, Dror G, et al. Minimizing brine discharge in a combined biophysical system for nitrate removal from inland groundwater. Separation and Purification Technology. 2015;156:496-501.

30. Gordon C, Wall K, Toze S, et al. Influence of Conditions on the Survival of Enteric Viruses and Indicator Organisms in Groundwater. Management of Aquifer Recharge for Sustainability. AA Balkema. 2002;133-138.

31. Xuejiao A, Yi Cheng, Mingyan H, et al. Treating organic cyanidecontaining groundwater by immobilization of a nitrile- degrading bacterium with a biofilm- forming bacterium using fluidized bed reactors. Environmental Pollution. 2018;237:908-916. 